\title{
男女格差の認知における社会的投射
}

\author{
田村美恵 \\ (神戸市外国語大学外国語学部) \\ キーワード : 社会的投射、男女格差、合意性推定
}

Social projection in perceptions of the prevalence of gender gap

Mie TAMURA

(Kobe City University of Foreign Studies)

Key Words: social projection, gender gap, consensus estimates

\begin{abstract}
近年、我が国においては、政治や経済のさまざまな場面で、 女性の人材活用や活躍の推進が叫ばれているが、その一方で、 依然として、賃金や人事面などでの男女格差については、改 善の兆しが見られない (e.g., “World economic forum”, 2013)。 その理由の一つに、固定的な性役割観の存在が指摘されてい る (e.g.,経済産業省, 2012)。性役割観に関する調査は繰り返 し行われているが（e.g., 内閣府, 2011）、重要なのは、そうし た性役割観が社会全体にどの程度流布、支持されているか(合 意性）に関する個々人の意識のあり方ではないかと思われる。 というのも、合意性がそれとして明示されることは希であり、 通常は個々人の推測に頼るほかないからである。一般に、人 は、ある事柄についての合意性を推測する際、「自己」の判断 や態度などを集団全体に投射／一般化する傾向がある。従来、 そうした投射は、外集団よりも内集団に対して顕著であると される（Robbins \& Krueger, 2005）が、こうした投射傾向は、 男女格差の認知に関しても見出されるだろうか。本研究では、 内集団、外集団、並びに（社会）全体に関する推定に「自己」 がどのように投射されるのかについて検討し、男女格差の認 知構造を探ることを目的とする。

\section{方 法}

調查参加者 公立大学の学生 252 名 (男 109 名、女 143 名)。 手続き 授業時間の一部を利用し、以下のような内容を含 む調查冊子を配布、回収した。

（1）男女間格差に関する合意性推定 男女の社会的地位や 性役割の格差に関する項目を 14 個作成した。各項目について、 男性集団、女性集団、（社会）全体集団に関する合意性（「賛 成」と回答する人々の割合)を 0 〜 $100 \%$ で推定してもらった。

(2) 自己態度の測定 上記項目に関する自分自身の回答を、

「賛成」か「反対」の二者択一で選択してもらった。

\section{結果と考察}

14 の合意性推定項目のうち、参加者自身の「賛成」の割合 が極端な值（80\%以上）であった 2 項目を除外し、残り 12 項 目について（全体集団に関寸る評定值に基づき）主成分分析 を行った結果、伝統主義的な性役割観（伝統主義）と平等主 義的な性役割観を反映する因子 (平等主義) が抽出された。 両因子に負荷量の高い 2 項目を除き 10 項目を分析対象とした。

\section{(1) 性役割観に基づく参加者の群分け}

「伝統主義」に属する 6 項目と「平等主義」に属する 4 項 目について、自己の回答が「賛成」であった場合に 1 点を与 え、因子毎に各評定項目の合計点を算出した。この值につい て、全参加者の平均值を算出し、伝統主義得点が平均值以上 で平等主義得点が平均值以下の者を「伝統派」、伝統主義得点 が平均值以下で平等主義得点が平均值以上の者を「平等派」 として各参加者を群分けした。

（2）内集団、外集団、全体集団の推定における社会的投射

内集団、外集団、全体集団に関寸る合意性推定において、 自己態度がどのように投射されるのかについて検討するため、 参加者毎に、10 個の合意性推定項目それぞれに対する自己の
回答（賛成または反対）と「賛成」に対する合意性推定值と の点双列相関係数を算出し、「投射指数」とした。值が高いほ ど、投射が強いことを示す。

参加者の性別、性役割観、及び対象集団別に投射指数の平 均を算出した（表 1)。これらを $z$ 值変換し、性別 $\times$ 性役割観 $\times$ 対象集団の分散分析を行った結果、性役割観 $(F(1,183)=4.38$, $p<.05)$ と対象集団 $(F(2,366)=26.55, p<.01)$ の主効果、性別 ×対象集団 $(F(2,366)=7.42, p<.01)$ 、性役割観 $\times$ 対象集団 $(F(2$, $366)=18.51, p<.01 ）$ の交互作用が有意であった。また、性別 $\times$ 性役割観 $\times$ 対象集団の 2 次の交互作用 $(F(2,366)=14.79, p<.01)$ が有意であったので、性別毎に下位検定を行った。

男性参加者について 性役割観 $\times$ 対象集団の単純交互作用 は見出されなかった $(F(2,366)=.12, n . s$.$) 。性役割観、対象集$ 団別に、各投射指数について、帰無仮説が $z^{\prime}=0$ で両側検定を 行った結果、すべての条件で、 $z$ 值が 0 と有意に異なっていた。 これらのことは、男性参加者においては、自己(の性役割観) は、伝統派であるか平等派であるかを問わず、内集団、外集 団、全体集団に等しく投射されることを示している。

女性参加者について 性役割観 $\times$ 対象集団の単純交互作用 が見出された $(F(2,366)=30.22, p<.01)$ 。下位検定の結果、平 等派では、対象集団の単純・単純主効果が得られた $(F(2,366)$ $=140.70, p<.01$ ）、多重比較の結果、投射指数は、内（女性）集 団で最も高く、外（男性）集団で最も低く、全体集団ではこ れらの中間であった。また、性役割観、対象集団別に各投射 指数について帰無仮説が $z^{\prime}=0$ で両側検定を行った結果、全て の条件で $z$ 值が 0 と有意に異なっていた。これらのことは、 平等派では、自己(の性役割観)は、内集団には正の方向で、 外集団には負の方向で投射される一方、全体集団に対しては、 それらを折半するかたちで投射されることを示している。

これに対して、伝統派では、対象集団の単純・単純主効果 は得られなかった $(F(2,366)=.63, n . s$.$) 。また、性役割観、対$ 象集団別に、各投射指数について帰無仮説が $z=0$ で両側検定 を行った結果、全ての条件で、 $z$ 值が 0 と有意に異なっていた。 これらのことは、伝統派では、自己（の性役割観）は、内集 団、外集団、全体集団に等しく投射されることを示している。 女性集団内に一定数存在する「伝統派」のこうした認知傾向 は、男性の伝統派とともに、男女格差を維持し、その解消を 阻む一因になっている可能性があると思われる。

表 1 性別、性役割観、対象集団別の投射指数の平均値

\begin{tabular}{ccccc}
\hline & & 全体集団 & 男性集団 & 女性集団 \\
\hline 男性 & 伝統派 & .522 & .388 & .477 \\
& 平等派 & .423 & .284 & .454 \\
\hline \multirow{2}{*}{ 女性 } & 伝統派 & .506 & .464 & .458 \\
& 平等派 & .397 & -.205 & .666 \\
\hline
\end{tabular}

